\title{
Modifiye Atmosfer Paketleme ve Normal Atmosfer Koşullarında Depolanan ''Roxana”’ Kayısı Çeşidinin Aroma Bileşenlerindeki Değişimler
}

\author{
Serpil Varlı Yunusoğlu ${ }^{*}$ Neslihan Ekinci ${ }^{\text {iD }}$ M. Ali Gündoğdu
}

Çanakkale Onsekiz Mart Üniversitesi, Ziraat Fakültesi, Bahçe Bitkileri Bölümü, Çanakkale

*Sorumlu yazar: Srpl.varli@gmail.com

Geliş Tarihi: 03.08.2021

Kabul Tarihi: 08.11.2021

\section{$\ddot{O} z$}

$\mathrm{Bu}$ çalışma ticari olum döneminde hasat edilen "Roxana', kayısı çeşidine ait meyveler ile yürütülmüştür. Meyveler hasattan sonra normal atmosfer (NA) ve modifiye atmosfer paketleme (MAP) koşullarında muhafaza edilmiş ve meyvelerin muhafaza süresince aroma bileşenlerinde meydana gelen değişimleri incelenmiştir. Hasat edilen meyvelere 1 gün süresince ön soğutma uygulanmış ve meyveler NA ve MAP koşullarında depolanmak üzere 2 gruba ayrılmıştır. Meyveler $0 \pm 0,5{ }^{\circ} \mathrm{C}$ sıcaklıkta ve $\% 90 \pm 5$ oransal nem koşullarında 45 gün süresince soğuk hava deposunda muhafaza edilmiştir. Hasattan hemen sonra başlangıç analizleri yapılmış ve muhafaza süresince 15 günlük periyotlarla analizler tekrarlanmıştır. Araştırma kapsamında suda çözünür toplam kuru madde miktarı (\%), titre edilebilir asitlik (\% malik asit), meyve eti sertliği (N), iç kararması şiddeti ve aroma bileşen kompozisyonu parametreleri incelenmiştir. Çalışmada MAP koşullarında muhafaza edilen meyvelerde, meyve eti sertliği ve titre edilebilir asitlik ölçümlerinde, NA koşullarında muhafaza edilen meyvelere kıyasla daha olumlu sonuçlar elde edilmiştir. Başlangıç analizlerinde 310,48 $\mu \mathrm{g} / \mathrm{kg}$ olarak bulunan hekzil asetat bileşeni, muhafaza süresinin sonunda artarak NA koşullarında 553,48 $\mu \mathrm{g} / \mathrm{kg}$, MAP koşullarında $501,78 \mu \mathrm{g} / \mathrm{kg}$ olarak tespit edilmiştir. MAP meyvelerde olgunlaşma hızını yavaşlatarak meyvelerin bozulmasını engellemiş ve böylece kayısının karakteristik aroma bileşenlerinin oluşumuna katkı sağlamıştır. Bu bileşenlerden olan lakton bileşenlerinin sentezinde MAP, NA muhafaza yöntemine göre daha başarılı olmuştur. Ancak diğer yandan 30 günlük muhafaza süresinin sonunda MAP içerisindeki $\mathrm{CO}_{2}$ bileşen oranının yükselmesi bu gruba ait meyvelerde iç kararması şiddetinin artmasına ve muhafaza sonuna doğru alkol bileşenlerinin yükselmesine neden olmuştur.

Anahtar Kelimeler: Prunus armeniaca L., Modifiye Atmosfer Paketleme, Soğukta Muhafaza

\section{Changes in Aroma Components of "Roxana" Apricot Cultivars Stored in Modified Atmosphere Packaging and Normal Atmospheric Conditions}

\section{Abstract}

This study was carried out with the fruits of the "Roxana" apricot variety harvested during the commercial maturity period. After harvest, the fruits were stored under Normal Atmosphere (NA) and Modified Atmosphere Packaging (MAP) conditions and the changes in the aroma components of the fruits during storage were investigated. Pre-cooling was applied to the harvested fruits for 1 day and the fruits were divided into 2 groups to be stored under NA and MAP conditions. Fruits were kept in cold storage for 45 days at $0 \pm 0,5{ }^{\circ} \mathrm{C}$ and $90 \pm 5 \%$ relative humidity conditions. Initial analyzes were made immediately after harvest and analyzes were repeated at 15-day intervals during storage. Within the scope of the research, total soluble solids contents (\%), titratable acidity (\% malic acid), fruit firmness $(\mathrm{N})$, internal browning and aroma component composition parameters were investigated. In the study, fruit firmness and titratable acidity measurements of fruits stored under MAP conditions were more positive than fruits stored under NA conditions. The hexyl acetate component, which was found as $310,48 \mu \mathrm{g} / \mathrm{kg}$ in the initial analysis, increased at the end of the storage period and was determined as 553,48 $\mu \mathrm{g} / \mathrm{kg}$ under NA conditions and $501,78 \mu \mathrm{g} / \mathrm{kg}$ in the MAP application. MAP slowed down the ripening rate in fruits and prevented the deterioration of fruits, thus contributing to the formation of characteristic aroma components of apricot. In the synthesis of lactone components, which are among these components, the MAP was more successful than the NA storage method. However, at the end of the 30-day storage period, the increase in the $\mathrm{CO}_{2}$ component rate in the MAP caused an increase in the severity of internal browning in the fruits belonging to this group and an increase in the alcohol components towards the end of storage.

Keywords: Prunus armeniaca L., Modified Atmosphere Packaging, Cold Storage 


\section{Giriş}

Son yıllarda tüm dünyada kayısı yetiştiriciliği yapılan alanların artmasıyla birlikte kayısı üretim miktarında da artış olmuştur. Türkiye'nin üretimin arttığı ülkeler arasında yer almasının yanı sıra, 2019 yılında tüm dünyada üretilen 4.252.241 ton kayısı üretiminin yaklaşı 985.000 tonluk bir kısmını üreterek, dünya kayısı üretimine \%25 katk1 sağladığ1 bilinmektedir (Anonymous, 2021; Anonim, 2021). Tüm dünyada kayısı taze meyve, konserve, reçel, meyve suyu, kurutulmuş meyve vb. şekilde değerlendirilmektedir (Ercişli, 2009). Ülkemizde kayısı üretiminde ilk sırada Malatya ili yer almakta ve bunu sırasıyla Elazığ, Erzincan, Kahramanmaraş, Mersin, Kars, Ankara ve Iğdır illeri takip etmektedir (Özbek, 1978; Ercisli, 2009). Yoğun yetiştiricilik yapılan bu iller dışında Çanakkale ilinde de taze tüketim için yoğun miktarda kayısı üretimi gerçekleştirilmektedir (Seker ve ark., 2018).

Meyvelerdeki optimum kalite kriterleri, hasat zamanındaki meyve gelişim aşamasına bağlı olduğu gibi başka faktörlere de bağlıdır. Meyve kalitesi hasat zamanının ilerlemesi ile artmaktadır. Ancak nakliye ve pazarlama zorlaştığı için üretici erken hasada zorlanmaktadır. Bu durum erken hasattan kaynaklanan, meyve aroması bakımından tüketici memnuniyetsizliğine yol açmıştır (Bruhn ve ark., 1991; Gómez ve Ledbetter, 1997). Tüketicilerin kayıs1 meyvesini tercih etme sebepleri de meyvelerin sulu, tatlı ve lezzetli olmasıdır (Azodanlou ve ark., 2003). Meyvelere özgü karakteristik aroma bileşenleri, bir meyvenin tüketici tarafından kabul görmesi için en önemli kriterdir. Meyvelerde aroma bileşenlerinin oluşum süreci dinamik olup, oldukça karmaşıłk bir süreçtir. Meyvelere özgü bu aroma bileşenleri genellikle, kayısı gibi klimakterik meyvelerde ticari olum döneminde hasat edildiği zaman oluşmamaktadır. Bununla birlikte aromatik bileşiklerdeki değişimler ve konsantrasyon miktarı çeşide, hasat sonrası işleme ve muhafaza koşulları ve süresine göre de değişkenlik göstermektedir (Aubert ve Chanforan, 2007). Fakat kayıs1 meyvelerinde hasattan sonra muhafaza sürecinin kalite özellikleri ile birlikte aroma bileşenlerine etkileri üzerinde yeterli çalışma bulunmamaktadır. Dünya genelinde kayısının aroma bileşenleri üzerine yapılan çalışmalarda genel olarak etil asetat, hekzil asetat, limonen, 6-metil-5-hepten-2-on, menton, E-hekzen-2-al, linalool, b-iyonon ve c-dekalaktondur gibi bileşikler rapor edilmiştir (Issanchou ve ark., 1989; Bolzoni ve ark., 1990; Greger ve Schieberle, 2007).

Ülkemiz kayısı üretiminde ilk sıralarda yer almasına rağmen, yaş kayısı ihracatında geri planda kalmaktadır. Bu sebeple kayısının taze olarak dayanımını geliştirmek gerekmektedir. Modifiye atmosferli paketleme (MAP) muhafaza yöntemi ile ortamdaki $\mathrm{O}_{2}$ miktarını azaltıp $\mathrm{CO}_{2}$ miktarı artırılabilmektedir (Bal, 2009). MAP, atmosferdeki yüksek karbondioksit konsantrasyonunu ve düşük oksijen ve etilen seviyesini ifade etmektedir. Bu materyaller, taze meyve ve sebzelerde hasat sonras1 kalite kayıplarını önlemek için gerekli bağıl nemi ve uygun sıcaklığı sağlayabilmek için kullanışlı ambalajlardır (Zagory ve ark., 1989). Kayısı klimakterik meyve grubunda yer aldığı için, hasat sonrası tazeliğini koruması ve buna uygun şekilde olgunlaştırılması gerekmektedir. Kayısı meyvelerinde olgunlaşma etilen hormonu ile ilişkilendirilmektedir (Bal, 2009). Büyüme, gelişme ve yaşlanma gibi olaylarda birçok aşamayı düzenleyen bir bitki hormonu olan etilen, ortaya çıktığı yer ve zamana göre hasadından sonra Bahçe Bitkileri ürünleri için yararlı olduğu gibi zararlı da olabilmektedir. Bu sebeple etilenin etkilerini ihtiyaçlarımız ile uyumlu bir şekilde birleştirerek, doğru bir hasat sonrası fizyolojisi denetiminin sağlanması ve kontrol mekanizmasına dönüştürülmesi gerektiği bildirilmiştir (Fidan ve Söylemezoglu, 1995). Diğer klimakterik meyveler gibi kayısı da yüksek oranda etilen gazı salgılar ve ayrıca yüksek seviyede etilene karşı hassastır. Etilenin olumsuz etkileri ve bununla paralel yumuşama ve olgunlaşma süreçlerini yavaşlatmak için soğukta muhafaza oldukça önemlidir (Mencarelli ve ark., 2006). Kayısı meyveleri çeşide bağlı olmakla birlikte $-0,5-0^{\circ} \mathrm{C}$ 'de $\% 90-95$ oransal nem koşullarında 34 haftaya kadar muhafaza edilebilir. Çeşitlerde donmaya dayanım \%10-14 arasında seyreden SÇKM değerlerine göre değişmektedir. Donma noktasının en düşük eşik sınırı $-1^{\circ} \mathrm{C}$ 'dir (Crisosto ve Kader, 1999; Thompson ve ark., 2008; Çalhan, 2010). Bu sebeple kayıs1 meyveleri, etilen sentezini engellemek amaciyla donma noktasının üzerinde olan $0 \pm 0,5{ }^{\circ} \mathrm{C}$ sicaklıkta depolanmaktadır. Aynı zamanda etilen, ortamdaki hava bileşenlerinden etkilendiği için, $\mathrm{CO}_{2}{ }^{\prime}$ nin ortamda yüksek oranda bulunması etilen sentezini inhibe eder ve özellikle klimakterik meyvelerde olgunlaşmayı yavaşlatarak meyvelerin depo ömrünü uzatır. Bu kapsamda çalışmamızın amacı kayısı meyvelerinin hasat sonrası dayanımını MAP ile uzatmak ve kayısı meyvelerinin aroma bileşenlerinde meydana gelen değişimleri incelemektir. 


\section{Materyal ve Yöntem}

\section{Bitkisel Materyal}

Kayısı meyveleri taşıma, nakliye ve depolama gibi ticari kaygılar nedeniyle, meyve zemin renginin yeşilden sarıya dönmeye başladığ 1 olgunluk döneminde (ticari olum dönemi) hasat edilir. $\mathrm{Bu}$ olgunluk dönemi optimum hasat zamanının saptanması için kullanılmaktadır (Scorza, 2005; Lichou ve ark.,2006; Çalhan, 2010).

Çalışmanın bitkisel materyali, "Roxana" kayısı çeşidinin ticari olum dönemine ait meyvelerden oluşmaktadır. 'Roxana' kayısı çeşidi ülkemizde son yıllarda tüketimi artan, bölgemizde de taze tüketim ve ihracat için yetiştiriciliği yapılan ve geç dönemde olgunlaşan bir çeşittir (Asma ve ark., 2006). Ağacı kuvvetli olup yayvan büyüyen sofralık bir çeşittir. Erken meyveye yatmakta ve verim orta yükseklikte olmaktadır. Meyve tutumu az olduğunda meyveleri oldukça iri olmaktadır (80$120 \mathrm{~g}$ ). Meyve kabuk rengi sarı zemin üzerinde koyu turuncu-kırmızı renkte olup, meyve eti turuncudur (Çalhan, 2010). Meyve bahçesi 4x5 m dikim mesafesi ile tesis edilmiştir. Meyve ağaçları 12 yaşında olup, çögür anacı üzerine aşılı ve verim çağındadır. Meyve ağaçlarında budama goble şeklinde yapılmıştır. Kayısılar Çanakkale ili merkez ilçeye bağlı Yapıldak köyüne ait arazide özel üreticiye ait bahçeden alınmış olup, arazi 40.138815 kuzey enlemi, 26.526146 doğu boylamında bulunmaktadır. Meyvelerin temin edildiği üretici bahçesinde; sulama, gübreleme, ilaçlama gibi kültürel işlemler düzenli olarak yapılmaktadır. Hasat işlemi elle yapılıp, meyve sapından yavaşça döndürülerek gerçekleştirilmiştir.

Meyveler hasat edildikten hemen sonra Çanakkale Onsekiz Mart Üniversitesi Ziraat Fakültesi Bahçe Bitkileri Laboratuvarına getirilmiş ve taşıma esnasında mekanik zarara uğrayan meyveler deneme dışında bırakılmışıı. Çalışmanın materyalini, sert olum dönemine ait, meyve kabuk rengini $\% 90$ oranında sağlayan ve meyve ağırlığı 65-85 g olan meyveler oluşturmuştur.

\section{Uygulama Materyali}

Hasat edildikten hemen sonra, meyvelere 1 gün süre ile hava ile ön soğutma uygulanmıştır. Meyveler hasat sonrası iki gruba ayrılmıştır. Birinci grupta yer alan meyvelere hiçbir uygulama yapılmamış, ikinci grupta yer alan meyveler ise MAP Lifepack ${ }^{\circledR}$ SCA-107 (Aypek Ltd. Şti, Bursa/Turkey) materyali ile kaplanmıştır. Tüm meyveler $0 \pm 0,5{ }^{\circ} \mathrm{C}$ sicaklıkta ve $\% 90 \pm 5,0$ oransal nem koşullarında 45 gün süre ile muhafaza edilmiştir. Depolama süresi boyunca soğuk hava depoları manuel olarak nemlendirilmiş ve her gün $10 \mathrm{dk}$ süre ile manuel olarak havalandırılmıştır.

\section{Meyve Eti Sertliği (N)}

Meyve eti sertliği (MES) Chatillon marka penetrometre ile $5.1 \mathrm{~mm}$ çapında silindir uç kullanılarak, Newton $(\mathrm{N})$ cinsinden ölçülmüsstür. Ölçümler meyvenin ekvatoral bölgesinde, her iki yanaktan $1 \mathrm{~cm}$ 'lik meyve kabuğunun uzaklaştırılıp, silindir ucun meyve etine $10 \mathrm{~mm}$ batırılması ile gerçekleştirilmiştir.

\section{Suda Çözünebilir Toplam Kuru Madde Miktarı (\%)}

Suda çözünebilir toplam kuru madde miktarı (SÇKM), hasadı yapılan 'Roxana" kayısı çeşidine ait 12 adet meyveden her birinden ayrı ayrı olmak üzere, meyve suyunun içindeki SÇKM miktarı el refraktometresi ile \% olarak ölçülmüştür.

\section{Titre Edilebilir Toplam Asitlik (\%)}

Meyveler bir homojenizatör yardımı ile parçalanmıştır. Homojen meyve püresinden elde edilen meyve suyundan $10 \mathrm{ml}$ örnek alınmış ve saf su ile 50 ml'ye tamamlanmıştır. Bu çözelti, manyetik karıştırıcı ve dijital $\mathrm{pH}$-metre kullanılarak 0,1 normal $\mathrm{NaOH}$ ile $\mathrm{pH} 8,1$ oluncaya kadar titre edilmiştir. Harcanan $\mathrm{NaOH}$ miktarı aşağıdaki formüle konarak hâkim organik asit (malik asit) \% olarak hesaplanmıştır.

$$
\text { Malik Asit }(\%)=\frac{S \times N \times F \times E}{C} \times 100
$$

S: Harcanan baz miktarı (ml)

$\mathrm{N}$ : Harcanan bazın normalitesi

F: Harcanan bazın faktörü

E: Asidin equvalent değeri (malik asit $=0,067$ ) 


\section{C: Örnek miktarı (ml)}

\section{Ambalaj İçi Gaz Konsantrasyonu}

Modifiye atmosfer paket uygulamalarında ambalaj içindeki $\mathrm{O}_{2}$ ve $\mathrm{CO}_{2}$ miktarı (\% mol) cinsinden ölçülmüştür. Ölçümler PBI GasDansensor cihazı yardımıyla haftada bir olacak şekilde gerçekleştirilmiştir. Söz konusu işlem; cihazın iğne uçlu probunun ambalaj materyali yüzeyine yerleștirilen silikon bariyer üzerinden ölçülmesiyle gerçekleştirilmiştir.

\section{Meyvelerdeki Aroma Bileşenlerinin Belirlenmesi}

Hasadı yapılan "Roxana" kayısı çeşidine ait meyvelerde etanol içeriğinin belirlenmesi amaciyla Vichi ve ark. (2003), Sabatini ve Marsilio (2008), Reboredo-Rodriguez ve ark. (2013) ile Ekinci ve ark. (2016), Seker ve ark. (2018) tarafindan tanımlanan yöntemler modifiye edilerek kullanılmıştır. Örneklerin analize hazırlanması (ekstraktsiyon) için homojenizatör ile elde edilen meyve pürelerinden $50 \mathrm{~g}$ örnek erlenmayer içinde $100 \mathrm{ml}$ dietil eter çözgeni ile muamele edilmiş ve çözücü 1 ml'ye santrifüj ve konsantratör yardımıyla derişikleştirilmiştir. Daha sonra GC/MS cihazında okuma yapılmıştır.

\section{Meyvelerde İç Kararması Şiddeti}

Tüm uygulamalara ait meyveler her 15 günlük depolama süresi sonunda kontrol edilmiş ve iç kararması şiddetini belirlemek amacıyla aşağıdaki skala kullanılarak meyveler sınıflandırılmıştır (Çalhan, 2010).

0 : İç kararması yok

1: İç kararması çok az

2: İç kararması az

3: İç kararması orta

4: İç kararması şiddetli

\section{Bulgular ve Tartışma}

NA ve MAP koşullarında muhafaza edilen ''Roxana'" kayısı çeşidine ait meyvelerin TEA, SÇKM, MES ve İç Kararması Şiddeti ölçümlerine ait değerler Çizelge 1'de verilmiştir. Hasattan sonra başlangıç analizlerinde $0,144 \mathrm{~g} / 100 \mathrm{mg}$ olarak ölçülen değer muhafaza süresinin artmasıyla düşüşe geçmiştir (Çizelge 1). Bu duruma muhafaza süresince meyvelerin solunum yapmaya devam etmesi ve solunum sırasında organik asitlerin kullanılması neden olabilmektedir (Dündar ve ark., 1997; Özkaya ve ark., 2005). Hasattan sonra meyvelerin SÇKM miktarı 7,75 değerinde ölçülmüşken, muhafaza süresince olgunluğun ilerlemesiyle orantılı olarak artış gerçekleştirmiş ve en yüksek artış NA koşullarında muhafaza edilen meyvelerde tespit edilmiştir (Çizelge 1). MAP uygulaması yapılan grupların meyvelerindeki bu düşük SÇKM oranının, ambalajlama uygulaması ile beraber $\mathrm{O}_{2}$ seviyesinin düşük olması, meyvenin daha yavaş solunum yapması ve su kaybının daha az olması ile ilgili olduğu düşünülmektedir. Deneme başlangıcında $31.90 \mathrm{~N}$ değerinde ölçülen MES değeri muhafaza süresinin sonunda NA koşullarında depolanan meyvelerde 6,58 N, MAP koşullarında ise 10,27 N değerinde ölçülmüştür (Çizelge 1). Meyvelerde gelişme aşamasında hücreler büyümekte ve hücreler arası boşluk artmaktadır. Bununla birlikte solunum ve biyokimyasal olaylar hızlanmaktadır. Poligalukturonaz, pektin esteraz, selülaz ve $\beta$-galakturonaz enzim aktivitesinin artmasına bağlı olarak hücre çeperi yapısındaki pektin, hemiselüloz ve selüloz parçalanmakta ve hücre yapısı bozulmaktadır. Olgunlaşma ve yaşlanma aşamasında tüm bu olaylar çok hızlı bir şekilde ilerlemekte ve meyvenin sertliği bu oranda azalmaktadır (Karaçalı, 2006; Barreıt ve Gonzalez, 1994; Fischer ve Bennett, 1991). Muhafaza süresince yapılan analizler sonucunda elde edilen verilerde uygulama* zaman interaksiyonu incelendiğinde 30 günlük depolama sonunda MAP'lı uygulamalarda iç kararmasının meydana geldiği saptanmıştır. NA koşullarında muhafaza edilen meyvelerde ise 45 günlük depolamanın sonunda iç kararması meydana gelmiştir (Çizelge 1). Depolama sonunda MAP koşullarında muhafaza edilen meyvelerde iç kararması şiddeti yüksek seviyede belirlenmiştir. MAP koşullarında iç kararmasının daha fazla olmasının $\mathrm{CO}_{2}$ oranı ile ilişkili olduğu düşünülmektedir. Meyveler $\mathrm{CO}_{2}$ seviyesinin $\% 5$ ve bunun üzerine çıktığı durumlarda, buna 2 haftadan daha uzun süre maruz kaldıklarında kahverengileşme ve tat-aroma kaybı meydana gelebilmektedir (Çalhan, 2010). Nitekim MAP içi hava bileşeni sonuçlarımızda da MAP uygulamasında, 28 günlük muhafaza periyodundan sonra $\mathrm{CO}_{2}$ oranı $\% 5$ üzerinde saptanmış ve bu durum bu uygulamada iç kararması şiddetinin en yüksek sonucu vermesine sebep olmuştur (Çizelge 1). 
Çizelge 1. 'Roxana'’ kayısı çeşidine ait meyvelerde hasat sonrası NA ve MAP koşullarında muhafaza edilen meyvelerdeki kalite kriterlerinin değişimi

\begin{tabular}{|c|c|c|c|c|c|c|}
\hline \multirow{7}{*}{$\begin{array}{c}\text { Titre } \\
\text { Edilebilir } \\
\text { Asitlik } \\
\text { (g/100mg) }\end{array}$} & Uygulama & Başlangıç & 15.Gün & 30.Gün & 45.Gün & ORT \\
\hline & NA & $0,144 \mathrm{~b}$ & $0,117 \mathrm{Bc}$ & $0,111 \mathrm{Bd}$ & $0,165 \mathrm{a}$ & $\mathbf{0 , 1 3 3}$ \\
\hline & & & & & & 0,135 \\
\hline & MAP & $0,144 \mathrm{a}$ & $0,140 \mathrm{Aa}$ & $0,105 \mathrm{Ab}$ & $0,152 \mathrm{a}$ & \\
\hline & ORT & 0,144 B & $0,128 \mathrm{C}$ & 0,108 D & 0,158 A & ------- \\
\hline & LSD & & & 112 & & ÖD \\
\hline & $\begin{array}{l}\text { LSD p<0,05 } \\
\text { (UygXSüre) }\end{array}$ & & & 0,0098 & & \\
\hline \multirow{6}{*}{$\begin{array}{c}\text { Suda } \\
\text { Çözünür } \\
\text { Kuru } \\
\text { Madde } \\
(\%)\end{array}$} & Uygulama & Başlangıç & 15.Gün & 30.Gün & 45.Gün & ORT \\
\hline & NA & $7,75 \mathrm{c}$ & $8,89 \mathrm{Ab}$ & $9,58 \mathrm{Ab}$ & $11,06 \mathrm{Aa}$ & 9,32 A \\
\hline & MAP & $7,75 \mathrm{~d}$ & $8,06 \mathrm{Bc}$ & $8,53 \mathrm{Bb}$ & $8,91 \mathrm{Ba}$ & 8,31 B \\
\hline & ORT & 7,75 C & 8,48 B & 9,05 B & 9,99 A & ------- \\
\hline & LSD & \multicolumn{4}{|c|}{0,6602} & 0,4668 \\
\hline & $\begin{array}{l}\text { LSD p<0,05 } \\
\text { (UygXSüre) }\end{array}$ & & & 0,6314 & & \\
\hline \multirow{6}{*}{$\begin{array}{c}\text { Meyve Eti } \\
\text { Sertliği (N) }\end{array}$} & Uygulama & Başlangıç & 15.Gün & 30.Gün & 45.Gün & ORT \\
\hline & NA & $31,90 \mathrm{a}$ & $14,94 \mathrm{Bb}$ & $9,99 \mathrm{Bc}$ & $6,58 \mathrm{Bd}$ & \multirow{2}{*}{$\begin{array}{r}15,85 \mathrm{~B} \\
19,51 \mathrm{~A}\end{array}$} \\
\hline & MAP & $31,90 \mathrm{a}$ & $20,08 \mathrm{Ab}$ & $15,78 \mathrm{Ac}$ & $10,27 \mathrm{Ad}$ & \\
\hline & ORT & $31,90 \mathrm{~A}$ & 17,51 B & $12,88 C$ & 8,43 D & ------- \\
\hline & LSD & & & 683 & & 1,1797 \\
\hline & $\begin{array}{l}\text { LSD p<0,05 } \\
\text { (UygXSüre) }\end{array}$ & & & 1,0608 & & \\
\hline \multirow{6}{*}{$\begin{array}{c}\text { İç } \\
\text { Kararması } \\
\text { Şiddeti }\end{array}$} & Uygulama & Başlangıç & 15.Gün & 30.Gün & 45.Gün & ORT \\
\hline & NA & $0,00 \mathrm{~b}$ & $0,00 \mathrm{~b}$ & $0,00 \mathrm{Bb}$ & $2,33 \mathrm{Ba}$ & \\
\hline & MAP & $0,00 \mathrm{c}$ & $0,00 \mathrm{c}$ & $1,67 \mathrm{Ab}$ & $3,66 \mathrm{Aa}$ & $1,33 \mathrm{~A}$ \\
\hline & ORT & $0,00 \mathrm{C}$ & $0,00 \mathrm{C}$ & $\mathbf{0 , 8 3 ~ B ~}$ & $3,00 \mathrm{~A}$ & ------- \\
\hline & LSD & \multicolumn{4}{|c|}{0,5629} & 0,398 \\
\hline & $\begin{array}{l}\text { LSD p<0,05 } \\
\text { (UygXSüre) }\end{array}$ & \multicolumn{5}{|c|}{$\mathbf{0 , 3 5 2 7}$} \\
\hline
\end{tabular}

*Ö.D.: Önemli değil (p>0,05); ORT: Ortalama; LSD: Asgari Önemli Farklılık

**Küçük harfler aynı UYGULAMA içerisindeki süre farklılı̆̆ını, **Büyük harfler ise aynı süre içindeki UYGULAMA farklılığını ortaya koymaktadır.

Farklı muhafaza koşullarında "Roxana"' kayısı çeşidine ait meyvelerin aroma bileşenleri Çizelge 2'de verilmiştir. Farklı konsantrasyonlarda, toplamda 24 adet aroma bileşeni ve bu bileşenlerinde fonksiyonlarına göre 6 aroma bileşen grubu tespit edilmiştir; Aldehitler (2 bileşen), Esterler ( 6 bileşen), Alkoller ( 7 bileşen), Ketonlar (3 bileşen), Laktonlar (3 bileşen), Terpenler (3 bileşen). Araştırmada muhafaza periyodu süresince, her iki gruba ait meyvelerde tespit edilen aroma bileşenlerinin konsantrasyonları arasında belirgin farklılıklar olduğu görülmüştür. 
Çizelge 2. "Roxana" kayısı çeşidine ait meyvelerin hasat sonrası NA ve MAP koşullarında muhafazası boyunca aroma bileşenlerindeki değişimi $(\mu \mathrm{g} / \mathrm{kg})$

\begin{tabular}{|c|c|c|c|c|c|c|c|c|}
\hline & \multirow[t]{2}{*}{ Bileşikler } & 0. Gün & 15. & 15.Gün & 30.Gün & 30.Gün & 45.Gün & 45.Gün \\
\hline & & Başlangıç & NA & MAP & NA & MAP & NA & MAP \\
\hline \multirow[b]{2}{*}{ Aldehitler } & Hekzenal & 265,89 & 149,45 & 219,40 & 83,91 & 106,13 & 0,00 & 31,49 \\
\hline & (E) -2-Hekzenal & 173,40 & 147,84 & 159,86 & 104,02 & 135,68 & 60,26 & 95,29 \\
\hline \multirow{7}{*}{ Alkoller } & 1-Hekzanol & 201,37 & 148,41 & 174,59 & 101,26 & 141,28 & 45,02 & 112,08 \\
\hline & 2-Propanol & 0,00 & 0,00 & 1,50 & 5,89 & 11,12 & 10,04 & 18,44 \\
\hline & Etanol & 1,40 & 2,58 & 2,75 & 3,45 & 5,81 & 4,12 & 7,85 \\
\hline & (E)-2-Hekzen-1-ol & 19,15 & 10,06 & 14,09 & 7,65 & 9,48 & 2,14 & 4,87 \\
\hline & 1-Butanol & 0,00 & 0,51 & 2,02 & 4,99 & 8,08 & 9,32 & 11,67 \\
\hline & 1-Heptanol & 0,00 & 5,58 & 7,89 & 11,20 & 13,61 & 20,49 & 23,61 \\
\hline & Z-3-hekzanol & 50,10 & 40,38 & 42,75 & 34,39 & 37,29 & 20,75 & 30,10 \\
\hline \multirow{6}{*}{ Esterler } & Hekzil asetat & 310,48 & 453,82 & 353,92 & 485,81 & 472,91 & 553,48 & 501,78 \\
\hline & Metil asetat & 5,20 & 10,58 & 8,47 & 15,48 & 12,92 & 12,53 & 11,35 \\
\hline & İsobutil asetat & 0,00 & 30,30 & 26,64 & 20,58 & 19,80 & 0,00 & 0,00 \\
\hline & İsobutil butanoat & 0,00 & 5,03 & 4,82 & 10,32 & 7,30 & 0,00 & 0,00 \\
\hline & Fenilasetaldehit & 90,32 & 80,18 & 89,42 & 60,72 & 81,31 & 40,75 & 50,10 \\
\hline & Propil asetat & 0,00 & 0,00 & 0,00 & 30,50 & 28,93 & 60,39 & 45,40 \\
\hline \multirow{3}{*}{ Ketonlar } & 1-Feniletanon & 7,30 & 14,74 & 9,28 & 8,40 & 6,40 & 3,72 & 4,30 \\
\hline & $\beta$-Lonon & 0,00 & 103,72 & 84,20 & 56,55 & 42,93 & 0,00 & 0,00 \\
\hline & Dihidro- $\beta$-iyonen & 0,00 & 0,00 & 0,00 & 175,30 & 160,38 & 75,60 & 144,30 \\
\hline \multirow{3}{*}{ Laktonlar } & r-Oktalakton & 67,69 & 75,50 & 123,86 & 101,46 & 174,16 & 155,91 & 211,43 \\
\hline & r-Dekalakton & 8,80 & 24,99 & 19,19 & 40,29 & 55,83 & 52,57 & 70,05 \\
\hline & $\gamma$-Undekalakton & 1,16 & 10,50 & 4,22 & 19,88 & 11,55 & 32,05 & 18,26 \\
\hline \multirow{3}{*}{ Terpenler } & Limonen & 26,93 & 12,03 & 15,29 & 4,29 & 7,29 & 0,00 & 1,26 \\
\hline & Linalol & 1,29 & 7,43 & 10,39 & 15,39 & 28,31 & 49,29 & 55,72 \\
\hline & $\beta$-Fellandren & 2,84 & 2,03 & 2,43 & 1,33 & 1,95 & 0,53 & 1,04 \\
\hline
\end{tabular}

Araştırma kapsamında aroma bileşen gruplarının ve kalite değerlerinin birbirleriyle ilişkilerinin daha rahat incelenebilmesi amacıyla biplot grafikleri kullanılmıştır (Şekil 1).

Biplot bilgi analizlerinde kullanışlı bir araç olup büyük bilgi matrislerinde görsel değerlendirme sağlamaktadır. Biplot birimler arası uzaklıkları gösterebilmekte ve birimleri korelasyon değerlerini kullanarak gruplandırabilmektedir (Gabriel, 1971).

Şekil 1'de görüldüğü gibi MES değeri ile alkol ve aldehit bileşenleri başlangıç analizlerinde ve 15 günlük MAP uygulamasında aynı eksende $(\mathrm{PC} 1<0$; $\mathrm{PC} 2>0)$ yer almaktadır. MES değeri ile alkol ve aldehit aroma bileşenleri bakımından en yüksek değerler bu iki uygulama-süre kombinasyonunda elde edilmiştir.

30. günde hem MAP hem NA uygulamaları SÇKM değeri ile ester ve keton aroma bileşen gruplarıyla aynı eksende $(\mathrm{PC} 1<0$; $\mathrm{PC} 2<0)$ yer almaktadır. Özellikle keton bileşen gruplarının söz konusu dönemde en yüksek değerlere sahip olduğu söylenebilmektedir (Şekil 1).

MAP ve NA uygulamalarının 45. gün ölçümlerinde iç kararması; titre edilebilir asitlik (TEA) değerleri ile, lakton ve terpen aroma bileşenleri ile aynı eksende yer almaktadır. Özellikle iç kararması ölçümleri ile lakton bileşenlerinin NA koşullarında depolanan meyvelerin 45. gününde daha yoğun 
olduğu gözlenmiştir. Bunun aksine MAP uygulamasının 45. gün ölçümlerinde ise TEA ölçüm değerleri ile terpen aroma bileşen gruplarının daha fazla olduğu tespit edilmiştir (Şekil 1).

Biplot grafiğinde ayrıca bileşen gruplarının birbirleriyle ilişkileri de belirlenmektedir. Alkol ve aldehit grupları ile MES ölçümlerinin aynı yönde ve çok yakın olduğu görülmüştür. Bu bileşen gruplarının tüm uygulamalar için, her muhafaza süresinde birbirleriyle yakın ilişkide olduğu ve pozitif korelasyon içerdiği gözlenmektedir. Ayrıca bu parametrelerin ester aroma grubu ve SÇKM ölçüm değerleri ile negatif korelasyonda bulunduğu da tespit edilmektedir. İç kararması ve TEA değerleri ile lakton ve terpen aroma bileşenlerinin, NA koşullarında 15. gün muhafaza süresinin tam ters ekseninde olduğu görülmüştür. Bu parametrelerin en düşük olduğu ölçümlerin, NA koşullarında 15 gün süre ile depolanan meyvelerde olduğu söylenebilmektedir. Ayrıca iç kararması ile lakton ve terpen aroma bileşen parametrelerinin birbirleriyle pozitif korelasyonda bulunduğu belirlenmiştir (Şekil 1).

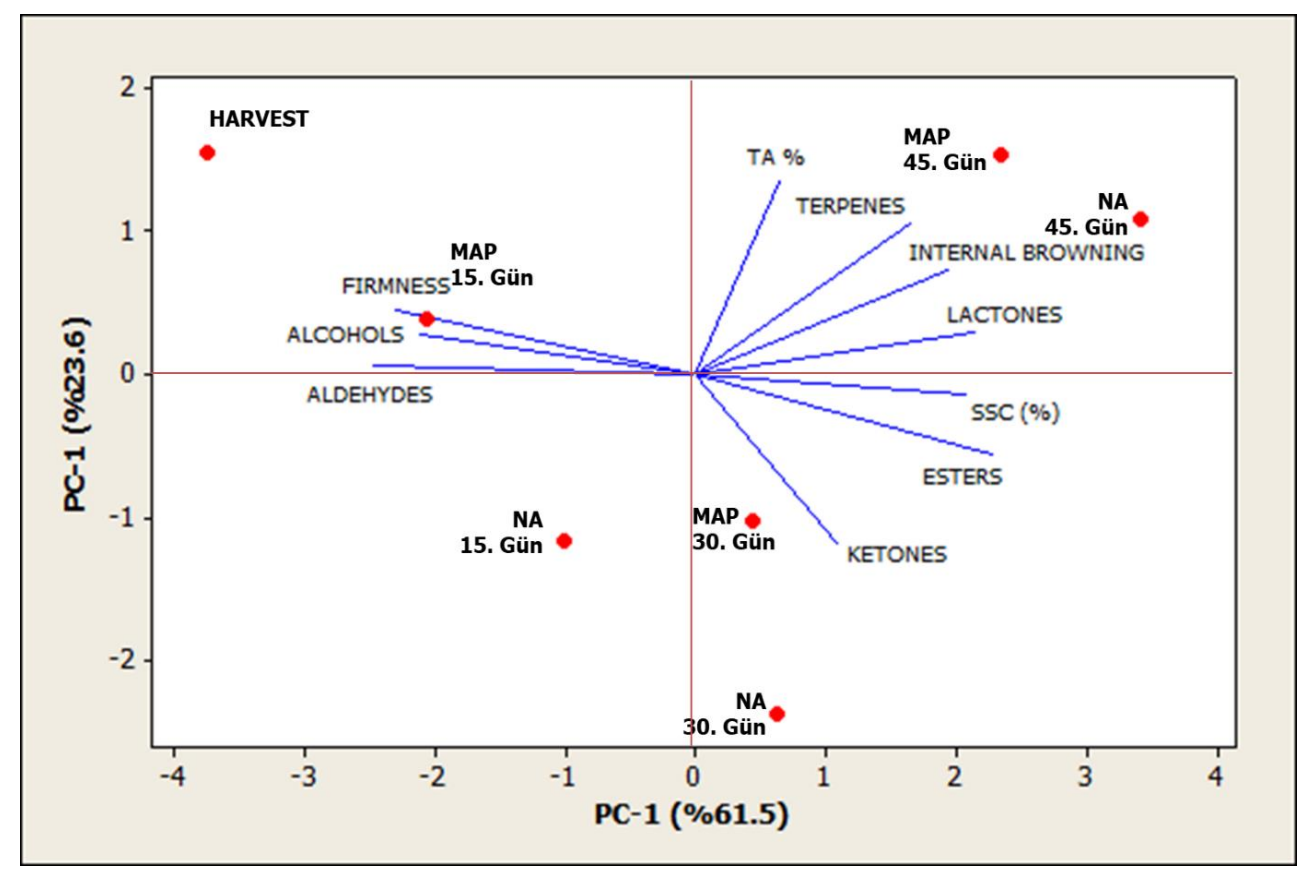

Şekil 1. "Roxana" kayısı çeşidine ait meyvelerin hasat sonrası NA ve MAP koşullarında muhafazası boyunca aroma bileşen gruplarının ve kalite değerlerinin birbirleriyle ilişkilerinin belirlendiği biplot grafiği

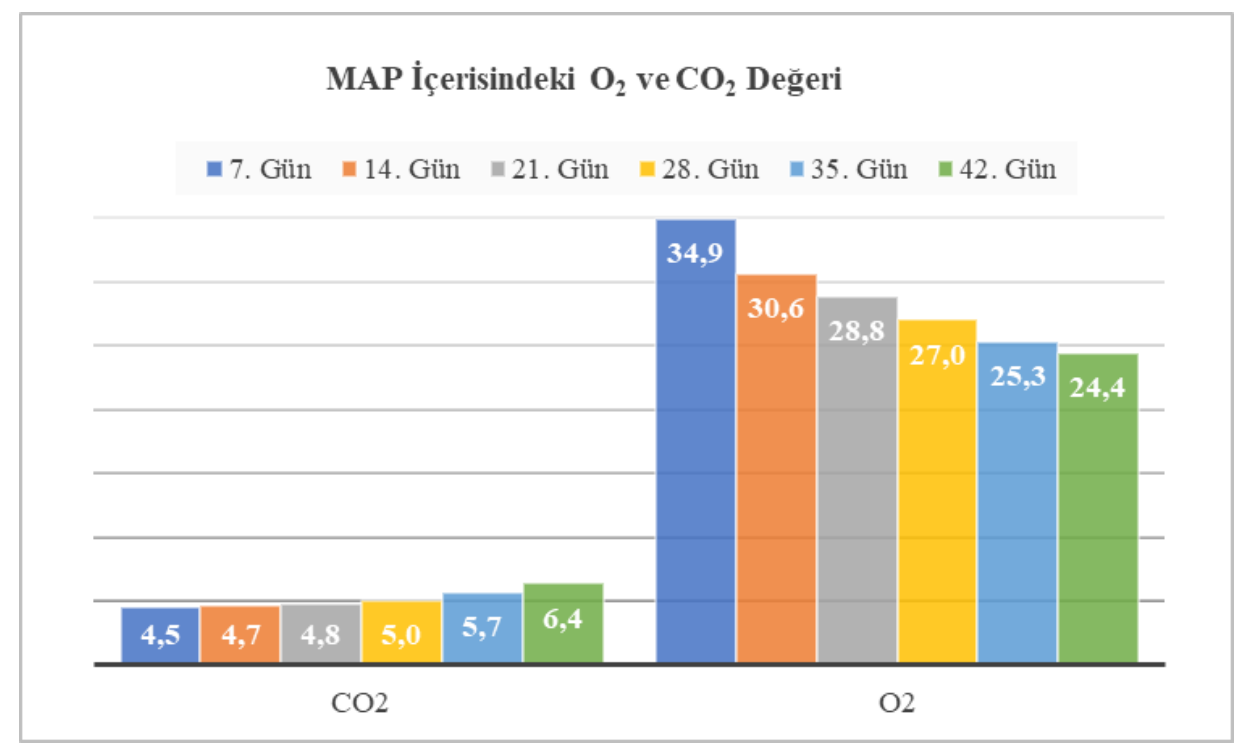

Şekil 2. MAP içerisindeki $\mathrm{O}_{2}$ ve $\mathrm{CO}_{2}$ bileşenlerinin (\% mol) değeri 
Yapılan analizler sonucunda aldehit grubu aroma bileşenlerinden hekzenal ve E-2-hekzenal bileşikleri tespit edilmiştir. Hekzenal ve (E)-2-hekzenal meyvelerde yeşil ve çimen kokusunu temsil eden bileşenler olarak bilinmektedir (Xi ve ark. 2016). Ticari olum döneminde hasadı yapılan meyvelerde yapılan ilk ölçümlerde, aldehit grubu bileşenleri yüksek miktarda bulunmuştur. Çalışmada elde edilen bulgulara benzer sonuçlar avokadoda yapılan bir çalışmada da elde edilmiş ve olgunlaşmamış avokadoda hezenal ve E-2-hezenal bileşenlerinin en bol bulunan bileşenler olduğu bildirilmiştir (Obenland ve ark. 2012). Kayısı meyvelerinde olgunluğun artmasıyla, her iki bileşende de miktar olarak düşüş gerçekleşmiştir. Hasattan sonra yapılan başlangıç analizlerinde $265,89 \mu \mathrm{g} / \mathrm{kg}$ olan hekzenal bileşiği, muhafaza periyodunun uzamasıyla ters orantılı olarak doğrusal bir şekilde düşüş gerçekleştirip, 45 günlük muhafaza süresi sonunda NA koşullarında depolanan meyvelerde tamamen kaybolmuş, MAP uygulamasının yapıldığı meyvelerde ise $31,49 \mu \mathrm{g} / \mathrm{kg}$ seviyesine kadar düşüş gerçekleştirmiştir. Yine bu yönde düşüş gerçekleştiren E-2-hekzenal bileşeni başlangıçta 173,40 $\mu \mathrm{g} / \mathrm{kg}$ seviyesinden, NA koşullarında muhafaza edilen meyvelerde $60,26 \mu \mathrm{g} / \mathrm{kg}$ ve MAP uygulamasına ait meyvelerde ise $95,29 \mu \mathrm{g} / \mathrm{kg}$ seviyesine kadar düşmüştür. İki grup arasındaki farklılıklar ele alındığında, MAP uygulamasının kayısı meyvelerinde olgunlaşmayı yavaşlattığı ve aldehit bileşenlerinin azalma hızını da bu oranda baskıladığı belirlenmiştir. Gómez ve Ledbetter (1997), kayısı meyvelerinde olgunlaşmanın artmasıyla paralel olarak aldehit grubu bileşenlerinin düşüşe geçtiğini bildirmişlerdir.

Araştırmada birçok ester grubu bileşeni tespit edilmiştir. Bunlar arasından hasattan hemen sonra yapılan başlangıç analizinde $310,48 \mu \mathrm{g} / \mathrm{kg}$ değeri ile ön plana çıkan hekzil asetat bileşeni, muhafaza süresinin ilerlemesiyle doğru orantılı olarak artış gerçekleştirmiş ve muhafaza süresinin sonunda NA'da muhafaza edilen meyvelerde 553.48, $\mu \mathrm{g} / \mathrm{kg}$ MAP uygulamasinda ise $501,78 \mu \mathrm{g} / \mathrm{kg}$ olarak bulunmuştur (Çizelge 2). Hekzil asetat bileşiği kayısının tipik aroma bileşenleri ile en iyi korelasyonu gösteren ve kayısı aromasına katkı sağlayan bir bileşik olarak tanımlanmaktadır (Guichard ve ark., 1990). Muhafaza süresince, NA koşullarında depolanan meyvelerde hekzil asetat bileşeninin konsantrasyon miktarı daha yüksek tespit edilmiştir. 'Roxana' kayısı çeşidine ait meyvelerde Fenilasetaldehit bileşeni hariç, diğer tüm bileşenler olgunluğun ilerlemesiyle beraber artma eğilimde olmuşlardır. Fenilasetaldehit bileşeni hasattan sonra 90,32 $\mu \mathrm{g} / \mathrm{kg}$ olarak tespit edilmiş ve 45 günlük muhafaza süresi sonunda NA koşullarında $40,75 \mu \mathrm{g} / \mathrm{kg}$, MAP koşullarında ise 50,10 $\mu \mathrm{g} / \mathrm{kg}$ değerinde bulunmuştur. Tespit edilen diğer ester bileşenleri incelendiğinde hasattan sonra yapılan başlangıç analizlerinde olmayıp, muhafaza süresinin ilerleyen dönemlerinde ortaya çıkan İsobutil asetat, İsobutil butanoat, Propil asetat bileşenleri dikkat çekmektedir. Bunlar arasından Propil asetat bileşeni muhafaza periyodunun son dönemine kadar artmaya devam ederken, İsobutil asetat ve İsobutil butanoat bileșenlerinde 30 günlük muhafaza süresinden sonra konsantrasyon miktarında azalma meydana gelmiştir (Çizelge 2). Bu bileşenler meyvede tatl1, meyvemsi ve muz gibi notaları temsil etmektedir. Muhafaza süresinin son döneminde meydana gelen azalma ile bu notalar yerine alkol arka plan aroması ağır basmıştır. Karabulut ve ark. (2018), yaptıkları çalışmada bu bileşenlerin hasattan sonra bulunmayıp olgunlaşma ile beraber görüldügünü ve ileri olgunluk döneminde ise kaybolduğunu bildirmişlerdir.

Çizelge 2 incelendiğinde, genel anlamda kayısı meyvesinin olgunlaşması ile paralel olarak ester bileşenlerinin artma eğiliminde olduğu görülmektedir. Ancak NA koşullarında muhafaza edilen meyvelerde bu artış oranı daha fazla olmuştur. Bu durumun, MAP koşullarında depolanan meyvelerde $\mathrm{CO}_{2}$ oranının yükselmesiyle birlikte iç kararması şiddetinin de artması ve bununla paralel alkol bileşenlerinin sentezlenmesi sonucu ester grubu bileşenlerindeki artışın baskılanmasından kaynaklandığı düşünülmektedir (Şekil 2). Muhafaza sonunda MAP koşullarında depolanan meyvelerde iç kararması şiddeti yüksek seviyede belirlenmiştir (Çizelge 1). MAP'lı uygulamada iç kararmasının daha fazla olmasının $\mathrm{CO}_{2}$ oranı ile ilişkili olduğu düşünülmektedir. Meyveler $\mathrm{CO}_{2}$ seviyesinin $\% 5$ ve bunun üzerine çıktığı durumlarda, buna 2 haftadan daha uzun süre maruz kaldıklarında kahverengileşme ve tat-aroma kaybı meydana gelebilmektedir (Çalhan, 2010). Bununla birlikte aldehitlerin, olgunlaşmanın ilerlemesiyle meyvelerde alkollere ve esterlere dönüştüğü bildirilmiştir (González-Agüero ve ark., 2009; Fellman ve Mattheis, 1995). Araştırmada alkol bileşenlerinin daha yüksek tespit edildiği MAP uygulamasında ester oranının baskılandığı 
saptanmıştır. Şekil 1'deki biplot grafiği incelendiğinde de alkol ve ester bileşen gruplarının birbirlerine zit eksende bulundukları görülmektedir.

Araştırmada hasattan sonra yapılan başlangıç analizlerinde 1-hekzanol, E-2 hekzan-1-ol, ve Z3-hekzanol bileşenlerinin bol miktarda bulunduğu görülmüştür (Çizelge 2). Gokbulut ve Karabulut (2012); González Agüero ve ark. (2009), bu bileşenlerin kayısı aromasına katkı sağladığını bildirmişlerdir. $\mathrm{Bu}$ üç aroma bileşeni de kayısı meyvelerinde olgunluğun artmasıyla düşüş trendine geçmiştir. Uygulamaların bu bileşenler üzerinde etkisi incelendiğinde MAP koşullarında muhafaza edilen meyvelerde olgunlaşmanın yavaş ilerlemesi sebebiyle, düşüş oranı, NA koşullarında muhafaza edilen meyvelere kıyasla daha yavaş gerçekleşmiştir. Yine hasattan sonra yapılan başlangıç analizlerinde görülen bir diğer alkol bileşeni olan etanol, muhafaza süresinin ve olgunlaşmanın artması ile doğru orantılı bir şekilde artış göstermiştir (Çizelge 2). Etanol bileşeni kayısı meyvesinde istenmeyen bir aroma bileşeni olup, meyvelerde alkol arka plan aroması özelliği göstermektedir. Çizelge 2 incelendiğinde MAP uygulamasına ait meyvelerde bu bileşenin konsantrasyon miktarının, NA koşullarında muhafaza edilen meyvelere kıyasla daha yüksek olduğu görülmüştür. Özellikle MAP uygulaması yapılan meyvelerde 30 günlük muhafaza süresinden sonra iç kararmasının görülmeye başlamasıyla etanol bileşenindeki artış hızının yükseldiği tespit edilmiştir. Diğer alkol bileşenlerinin değişimi incelendiğinde 2-propanol, 1-butanol ve 1-heptanol bileşenlerinin hem muhafaza süresince değişimleri hem de uygulamalar arasındaki farklılıkları açısından, etanol bileşeni ile aynı doğrultuda bir reaksiyon sergiledikleri görülmüştür. Genel anlamda MAP uygulamasında, 30 günlük muhafaza süresinin sonunda artan $\mathrm{CO}_{2}$ seviyesi nedeniyle kayısı meyvelerinde alkol bileşenlerinin hızlı bir şekilde sentezlendiği saptanmıştır.

Hasattan sonra yapılan başlangıç analizlerinde keton grubu bileşenleri arasından sadece 1feniletanon bileşeni, $7,30 \mu \mathrm{g} / \mathrm{kg}$ değeri ile tespit edilmiştir. $\beta$-lonon ve dihidro- $\beta$-iyonen bileşenleri olgunluğun ilerlemesiyle ortaya çıkmıştır (Çizelge 2). Dihidro- $\beta$-iyonen ve $\beta$-lonon bileşenleri kayısı meyvesinin aroması için önemli bileşenlerdendir (Takeoka ve ark 1990; Chariote ve ark 1981; Gómez ve Ledbetter, 1997). Keton bileşen grubu genel olarak olgunluğun artmasıyla beraber önce artıp, daha sonra bir azalma eğilimi göstermiştir (Çizelge 2). Şekil 1 incelendiğinde keton bileşen grubu ile alkol bileşen grubu ters eksen üzerinde yer almış, alkollerin varlığı ile keton bileşenlerinin sentezinin engellendiği belirlenmiştir.

Kayısı meyveleri için diğer bir önemli bileşen grubu laktonlardır. Laktonlar kayısıya özgü karakteristik aromanın oluşmasına katkı sağlayan en önemli bileşen gruplarıdır (Gómez ve Ledbetter, 1997; Karabulut ve ark., 2018). Araştırmada lakton bileşen grubunun muhafaza süresince değişimi incelendiğinde, muhafaza süresinin artışıla paralel olarak olgunluğun ilerlemesiyle birlikte artışa geçtikleri tespit edilmiştir. Laktonlar kayısı meyvelerinde meyvemsi, hindistan cevizi ve şeftali arka plan aromasına katkı sağlamaktadır (Guichard ve ark., 1990; Takeoka ve ark., 1990). Muhafaza süresinin sonunda uygulamaların lakton bileşenleri üzerindeki etkisi incelendiğinde MAP uygulamasının laktonlar üzerinde olumlu etkisi olduğu görülmüştür. NA koşullarında muhafaza edilen meyvelerde tat ve aroma oluşumu belli bir seviyeye kadar iyi ilerlemiştir. Ancak yaşlanmanın ve buna paralel olarak bozulmanın artmasıyla tat ve aromadaki olumlu ilerleme, MAP uygulamasına göre geri planda kalmıştır.

Çalışmada terpen grubu bileşenlerinin muhafaza süresince değişimi ele alındığında hasattan sonra yapılan başlangıç analizlerinde $26,93 \mu \mathrm{g} / \mathrm{kg}$ değeri ile limonen bileşeni dikkat çekmektedir. Limonen muhafaza süresinin artmasıyla ters orantılı olarak azalma göstermiştir. Meyveler sert olum döneminde hasat edildiği için limonen konsantrasyonu yüksek seviyede çıkmıştır (Çizelge 2). Çünkü limonen meyvelerde turunçgil ve meyvemsi aroma karakterinden sorumludur (Guillot ve ark. 2006). Uygulamalar arasındaki farklılık incelendiğinde MAP uygulamasının limonen konsantrasyonundaki düşüş hızını yavaşlattığı görülmüştür. $\mathrm{Bu}$ durum $\mathrm{MAP}$ uygulamasının olgunlaşma hızını yavaşlatmasından ileri gelmektedir (Çizelge 2). Kayısı aroması için önemli olan bir diğer terpen grubu aroma bileşeni ise linaloldür ve meyve aromasında çiçeksi arka plan aromasına sahiptir (Karabulut ve ark., 2018; Aubert ve Chanforan, 2007). MAP koşullarında muhafaza edilen meyvelerde linalol konsantrasyonunun, NA koşullarında muhafaza edilen meyvelere kıyasla daha yüksek olduğu tespit edilmiştir (Çizelge 2). Bu da NA koşullarında meyve olgunlaşma hızının ve bozulma oranının artmasıyla ilişkilendirilmiştir. 


\section{Sonuç}

Hasat sonrası farklı muhafaza koşullarında depolanan 'Roxana" kayısı çeşidine ait meyvelerde Aldehitler ( 2 bileşen), Esterler ( 6 bileşen), Alkoller ( 7 bileşen), Ketonlar ( 3 bileşen), Laktonlar ( 3 bileşen), Terpenler ( 3 bileşen) olmak üzere 6 aroma bileșen grubu ve toplamda 24 adet aroma bileşeni tespit edilmiştir. Muhafaza periyodu süresince, her iki gruba ait meyvelerde tespit edilen aroma bileşenlerinin konsantrasyonları arasında belirgin farklılıklar olduğu görülmüştür. MAP koşullarında muhafaza edilen meyvelerde meyve eti sertliği ve TEA ölçümlerinde, NA koşullarında muhafaza edilen meyvelere kıyasla daha olumlu sonuçlar elde edilmiştir. İki grup arasındaki farklılıklar ele alındığında, MAP uygulamasının kayısı meyvelerinde olgunlaşmayı yavaşlattığı ve aldehit bileşenlerinin azalma hızını da bu oranda baskıladığ 1 tespit edilmiştir. Kayısı meyvelerinde ester grubu bileşenlerinden Fenilasetaldehit bileşeni hariç, diğer tüm ester bileşenleri olgunluğun ilerlemesiyle beraber artma eğilimde olmuştur. Fenilasetaldehit bileşeni hasattan sonra $90,32 \mu \mathrm{g} / \mathrm{kg}$ olarak tespit edilmiş ve 45 günlük muhafaza süresi sonunda NA koşullarında 40,75 $\mu \mathrm{g} / \mathrm{kg}$, MAP koşullarında ise $50,10 \mu \mathrm{g} / \mathrm{kg}$ değerinde bulunmuştur. Yine MAP uygulaması kayısının karakteristik aroma bileşenleri olan lakton grubu bileşenlerinin sentezine katk1 sağlamada en iyi uygulama olmuştur. Öte yandan 30 günlük muhafaza süresinin sonunda MAP içerisindeki $\mathrm{CO}_{2}$ bileşen oranının yükselmesi bu gruba ait meyvelerde iç kararması şiddetinin artmasına ve muhafaza sonuna doğru alkol bileşenlerinin yükselmesine neden olmuştur. Araştırmada alkol bileşenlerinin daha yüksek tespit edildiği MAP uygulamasında ester oranının baskılandığı saptanmıştır. Terpen grubu bileşenlerinden olan ve meyvelerde turunçgil ve meyvemsi aroma karakterinden sorumlu olan limonen, meyveler sert olum döneminde hasat edildiği için başlangıç analizlerinde yüksek seviyede çıkmıştır. Muhafaza süresinin uzaması ile limonen konsantrasyonunda azalma meydana gelmiştir. Uygulamalar arasındaki farklılık incelendiğinde MAP uygulamasının limonen konsantrasyonundaki düşüş hızını yavaşlattığı görülmüştür. Bu durum MAP uygulamasının olgunlaşma hızını yavaşlatmasından ileri gelmektedir.

\section{Kaynaklar}

Anonim, 2021. http:// http://www.tuik.gov.tr/. Erişim tarihi: 04.2021

Anonymous, 2021. http://www.fao.org. Data Accessed: 04.2021

Asma, B.M., Kan, T., Birhanl, O., Erdoğan, A., 2006. Geç Olgunlaşan Sofralık Kayısıların Melezleme Yoluyla Islahı (I. Dilim). TÜBİTAK Proje No: TOGTOG-3099. Nisan 2006, Malatya.

Aubert, C., Chanforan, C., 2007. Postharvest changes in physicochemical properties and volatile constituents of apricot (Prunus armeniaca L.). Characterization of 28 cultivars. Journal of Agricultural and Food Chemistry. 55(8): 3074-3082.

Azodanlou, R., Darbellay, C., Luisier, J.L., Villettaz, J.C., Amadò, R., 2003. Development of a model for quality assessment of tomatoes and apricots. Lebensmittel-Wissenschaft und-Technologie. 36: 223-233.

Bal, E., 2009. Hasat Sonrası Potasyum Permanganat, UV-C, Salisilik Asit ve Sicaklık Uygulamalarının Kivi Kalitesi ve Muhafaza Süresi Üzerine Etkileri. Namık Kemal Üniversitesi Fen Bilimleri Enstitüsü, Doktora Tezi.

Barrelt DM., Gonzalez C., 1994. Activity of softening enzymes during cherry maturation. Journal of Food Science. 59(3): 574-577.

Bolzoni, L., Careri, M., Mangia, A., 1990. Characterization of volatile components in apricot purées by gas chromatography-mass spectrometry. Journal of Chromatography. A(518): 221-229.

Bruhn, C., Feldman, N., Garlitz, C., Harwood, J., Ivans, E., Marshall, M., Riley, A., Thurber, D., Williamson, E., 1991. Consumer perceptions of quality: apricots, cantaloupes, peaches, pears, strawberries, and tomatoes. J. Food Quality. 14 187亡̀195.

Chariote, G., Rodriguez, F., Crouzet, J., 1981. Characterization of additional volatile Ñavor components of apricot. J. Food Sci. 46 1898È1901.

Crisosto, C.H., Kader, A.A., 1999. Apricots Postharvest Quality Maintenance Guidelines.

Çalhan, Ö., 2010. Bazı depolama koşullarının Roxana kayısı çeşidinin soğukta muhafazası üzerine etkileri. Süleyman Demirel Üniversitesi Fen Bilimleri Enstitüsü, Bahçe Bitkileri Anabilim Dalı, Yüksek Lisans Tezi.

Dundar, O., Kuden, A.B., Dennis, F.G., 1997. Jr Investigations on cold storage and post harvest physiology of J. H. Hale Peach. Acta Hortic. 441: 411-441.

Ekinci N., Şeker M., Gündoğdu M.A., 2016. Effects of Post-Harvest Dippings of Calcium Oxide on Aroma Volatile Compound of Pink Lady Apple Cultivar. VII. Int. Sci. Agric. Sym. (Agrosym). Book of Proceedings. 6-9 October, Jahorina, Bosnia and Herzegovina. 
Ercisli, S., 2009. Apricot culture in Turkey. Sci. Res. Essay. 4(8): 715-719.

Fellman, J. K., Mattheis, J. P., 1995. Ester biosynthesis in relation to harvest maturity and controlled-atmosphere storage of apples. pp. 149-162.

Fidan, Y., Söylemezoğlu, G., 1995. Bahçe Bitkilerinin Hasat Sonrası Fizyolojisi Açısından Etilenin Önemi, Biyosentezi ve İşleyiş Mekanizması. Gıda. 20(1).

Fischer RL., Bennett AB., 1991. Role of cell wall hydrolases in fruit ripening. Annual review of plant biology 42(1): 675-703.

Gabriel, K. R., 1971. The biplot graphic display of matrices with application to principal component analysis. Biometrika. 58(3): 453-467.

Gokbulut I, Karabulut I., 2012. SPME-GC-MS detection of volatile compounds in apricot varieties. Food Chem. 132:1098-1102.

Gómez, E., Ledbetter, C. A., 1997. Development of volatile compounds during fruit maturation: characterization of apricot and plum $\times$ apricot hybrids. Journal of the Science of Food and Agriculture. 74(4): 541-546.

González-Agüero, M., Troncoso, S., Gudenschwager, O., Campos-Vargas, R., Moya-León, M. A., Defilippi, B. G., 2009. Differential expression levels of aroma-related genes during ripening of apricot (Prunus armeniaca L.). Plant physiology and biochemistry. 47(5): 435-440.

Greger, V., Schieberle, P., 2007. Characterization of the key aroma compounds in apricots (Prunus armeniaca) by application of the molecular sensory science concept. Journal of Agricultural and Food Chemistry. 55: 5221-5228.

Guichard, E., Schlich, P., Issanchou, S., 1990. Composition of apricot aroma: correlations between sensory and instrumental data. Journal of Food Science. 55(3), 735-738.

Guillot S., Peytavi L., Bureau S., Boulanger R., Lepoutre J.P., Crouzet J., Schorr-Galindo S., 2006. Aroma characterization of various apricot varieties using headspace-solid phase microextraction combined with gas chromatography-mass spectrometry and gas chromatography-olfactometry. Food Chem. 96: 147155.

Issanchou, S., Schlich, P., Guichard, E., 1989. Odour profiling of the components of apricot flavour. Description by correspondence analysis. Sciences des Aliments. 9: 351-370.

Karabulut, I., Gokbulut, I., Bilenler, T., Sislioglu, K., Ozdemir, I. S., Bahar, B., Seyhan, F., 2018. Effect of fruit maturity level on quality, sensory properties and volatile composition of two common apricot (Prunus armeniaca L.) varieties. Journal of food science and technology. 55(7): 2671-2678.

Karaçalı, İ., 2006. Bahçe ürünlerinin muhafaza ve pazarlanması. Ege Üniversitesi Ziraat Fakültesi Yayınları No:494, 481s. İzmir.

Lichou, J., Jay, M., Chamet, C., Pinet, C., Broquaire, J.M., 2006. The Apricot Colour Chart: For a Picking at Optimal Maturity. Acta Horticulturae. 701: 551-552.

Mencarelli, F., Bellincontro, A., Forniti, R., Vizovi-tis, K., Botondi, R., Valentini, M., Sequi, P., DiNata-le, C., Basile, B., Romano, R., 2006. Factors Affec-ting The Apricot Quality for the Consumer with Special Attention to the Use of 1- MCP and of NDT for Detection of Bruising. Acta Horticultu-rae. 717: 315 320.

Obenland, D., Collin, S., Sievert, J., Negm, F., Arpaia, M. L., 2012. Influence of maturity and ripening on aroma volatiles and flavor in 'Hass' avocado. Postharvest Biol Technol. 71:41-50.

Özbek, S., 1978. Özel Meyvecilik. Çukurova Ü. Ziraat Fak. Yayınları, No: 128, Adana.

Özkaya, O., Dündar, Ö., Küden, A., 2005. Adana koşullarında yetiştirilen angeleno erik çeşidinin muhafaza performansı. III. Bahçe Ürünlerinde Muhafaza ve Pazarlama Sempozyumu. Mustafa Kemal Üniversitesi. 406-408, Antakya-Hatay.

Reboredo-Rodríguez, P., González-Barreiro, C., Cancho-Grande, B., and Simal-Gándara, J., 2013. Aroma biogenesis and distribution between olive pulps and seeds with identification of aroma trends among cultivars. Food chemistry. 141(1): 637-643.

Sabatini, N., and Marsilio, V., 2008. Volatile compounds in table olives (Olea Europaea L., Nocellara del Belice cultivar). Food chemistry. 107(4): 1522-1528.

Scorza, R., 2005. Peach and Apricot (Chapter 19). In: Processing Fruits Science and Technology (2nd). (Barrett, D.M, Somogyi, L, Ramaswamy, H., -eds.). CRC Press, pp: 481-496. Boca Raton.

Seker, M., Gur, E., Ekinci, N., Gundogdu, M. A., 2018. Volatile Constituents of Different Apricot Varieties in Cool Subtropical Climate Conditions. Horticult Int J. 2(5): 237-242.

Takeoka, G., Flath, R., Mon, T., Teranishi, R., Guentert, M., 1990. Volatile constituents of Apricot (Prunus armeniaca L). J Agric Food Chem. 38 471̇̀477.

Thompson, J.F., Mitchell, F.G., Rumsey, T.R., Kasmire, R.F., Crissto, C.H., 2008. Commercil Cooling of Fruits, Vegetables, and Flowers. Univ. Of California, Agricultural and Natural Resources Publ. 21567.

Vichi, S., Pizzale, L., Conte, L. S., Buxaderas, S., López-Tamames, E., 2003. Solid-phase microextraction in the analysis of virgin olive oil volatile fraction: modifications induced by oxidation and suitable markers of 
ÇOMÜ Zir. Fak. Derg. (COMU J. Agric. Fac.)

2021: 9 (2): 399-410

ISSN: $2147-8384$ / e-ISSN: 2564-6826

doi: 10.33202/comuagri.978042

oxidative status. Journal of Agricultural and Food Chemistry. 51(22): 6564-6571.

Xi, W., Zheng, H., Zhang, Q., Li, W., 2016. Profiling taste and aroma compound metabolism during apricot fruit development and ripening. Int J Mol Sci. 17: 998-1020.

Zagory, D., Kerbel, E. L., Kader, A. A., 1989. Modified atmosphere packaging of fruits and vegetables. CRC Rev. Food Sci. Nutr. 28(1): 1-30. 